\title{
Encapsulating the Translatory Attributes in the Formulation and Development of the Selected Modernist Building Constructed in Islamabad, Capital of Pakistan
}

\author{
Mansoor Ahmed \\ Department of Architecture and Design, COMSATS, Lahore
}

Email: mansoordeahmed@gmail.com

\section{ARTICLE INFORMATION}

Received:August 30, 2016

Revised: October 18, 2016

Accepted: December 15, 2016

Published online: January 02, 2017

Keywords:

National Identity, Modernity and New

Nations State.

\begin{abstract}
Right after the construction of Islamabad, National Capital of Pakistan, different foreign architectswere hired by the State to undertake landmark projects in the city. Most notable among them were Doxiadis, Kenzo Tange, Edward Durell Stone. The preference given to these foreign architects over the local architect was tied to the inherited ideas of Modernist Supermacy, 'glorified western cultures' and their understanding of the traditional architecture specifically the so called, Islamic architecture. It was assumed that the architecture, foreign architects will produce would be technologically advanced, help in the International recognition of national architecture and become a symbol of Nation's progression. The paper focusses on a comparative critique of the two landmark projects namely Presidential Estate and Pakistan Atomic Energy Commission building (PAEC) named as Pakistan Institute of Nuclear Science and Technology (PINSTECH), both situated in Islamabad and designed by Edward Durell Stone. These two buildings have been analysedwith reference to the background forces, in line to Foucault's term,narrated as political power, subjectivity and resistance. The research has anchored on the idea that in line with the official brief, the former project was not only inspired byInternationalstyle,but also adapted to the Mughal gardens in terms ofgrandeur and spatial construction. On the other hand, PINSTECH building can be read as an effort of the forceful marriage of states religious subjectivities and Modernity. The paper concludes with 'folk architecture' a term coined by Doxiadis and reading it in conjunction with the architectural anomalies.
\end{abstract}

\section{Introduction}

In her seminal book "Esra Akcan" defines translation as "any act of changing from one place, position, condition, medium or language" [1].Keeping this definition as a broader framework for operation, this paper has developed a criticism of the "two" seminal projectsdesigned by Edward Durrell Stone (EDS), after Independence of Pakistan in 1947. These projects present a critical discourse on the post-independence modernistarchitecture in Pakistan. The analysis of this discourse has highlighted that how background forces like power, representation and national identityhelped in shaping the architecture in a newly formed country. EDS was born in Arkansas and actively engaged in the practice of architecture across the globe. He was also an active member of CIAM. Being a foreign architect (in Pakistan)and widely recognized as "Modernist populous architect" [8] ,the selection of EDS as an architect to design some of the landmark buildings in Pakistan was made after he displayed an elaborate understanding of the local architectural tradition, especially Mughal architecture ${ }^{1}$. The 'Islamic' debate remained in the core of theideological development of architecture in the new state. Apart from the progressive approach andliberal agendas of ruling martial law regime, the main reason for overly emphasizingthe religious ethos in architecture was to provide an authenticity to their rule by manipulating peoples aspiration.

Thisamalgamation of new and old had become a challenge for architects and resulted in the competitive selection of EDS. Though highly criticized by the architect and theorist,Kamil Khan Mumtaz (KKM)the design of Wapda House (Offi of Water and Power Development Authority) in Lahore [18] by EDS and the other projects undertaken by him helped in developing a hybrid architecture style in Pakistan. Theseworks also provided a platform for synthesis of opposing ideas and

${ }^{1}$ Pakistan came into being and seperated from India, following the two nation-theory, and post-independece rulers wants to validate the the national architecture by connecting it with the Great Mughals, (muslim rulers of India), at the same time keepin it in par with the pervailing ideas of modernity and progression. 
provided a culminating point for progressive modernity and local tradition. This hybridity not only helped in successful incorporation of the State's agenda in architecture but also provided a guideline forthefuturearchitectural development.

The following lines would try to decipher the issue in translation concerning the EDS's two seminalprojects designed in Pakistan namely the Presidential Estate and the Pakistan Institute of Nuclear Science and Technology (PINSTECH) at Islamabad. These buildings were designed not only to serve a straight forward function but because of their political importance, also subjected to bear the burden of identity and representation. The 'PresidentialEstate' was the center of the political power in the newly developed capital Islamabad, while 'Pakistan Institute of Nuclear Science and Technology' was founded to bring the country in line with thesuperpowers, (beholding atomic power), and to make Pakistan invincible. Hence in both the projects, power was operative with full force, as defined by Foucault,as "an instrument of coercion".

\section{The Presidential Estate}

Immediately after the Independence in 1947, the quest for Pakistani architecture has started. Born on the crossroad of civilization, Pakistan spans over a geographical location which includes some of the greatest civilizations of ancient and medieval period. The most prominent of them are Indusvalley civilization (3000 BC), Gandhara civilization (1500 BC), Mughal period ( 1526-1857), and British colonial period (1857-1947). People in Pakistan had a

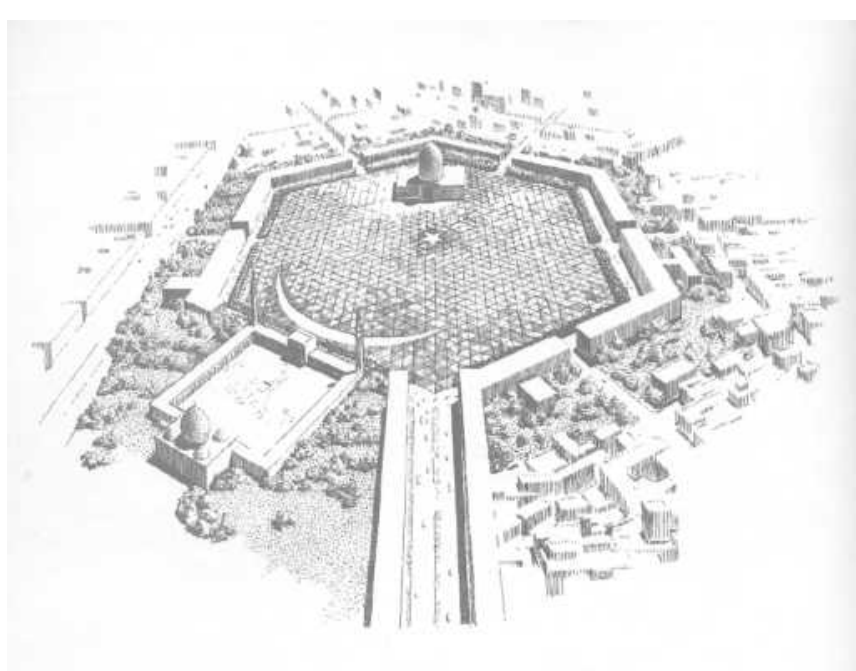

Figure 1a. Proposed Sketch for the Central Square in Karachi - The First Federal Capital of Pakistan. strong affiliatio with these civilizations, more specifically with the Mughals, which is regarded as a Muslim renaissance in India [11]. After the independence, the port city of Karachi was selected as the National Capital of Pakistan, which was being retrofitted to accommodate the State's function. However, the first proper master plan for Karachi (then national capital) was proposed by Swedish firm Merz Rendall Vatten (MRV) in 1952. This proposal is commonly known as MRV plan [6]. Aview of their proposed sketch (Fig 1A) for the Capitol complex in Karachi would help in understanding the development of the Presidential State in Islamabad. The sketch reveals the proposed agenda of the state and how architects translated it. The plan was designed using geometry as acore tool for spatial development, which placed it in comparison with the spatial configuration of plans developed for the building utilized by Muslims in theIndian subcontinent and labeled as 'so-called' Islamic architecture. The plan also shows the placement of the Grand National mosque at a central location thus truly reflecting the prevailing discourse in the plan of the Capital. The inclusion of architectural features like 'Onion-shaped domes' and 'courtyard' highlights thearchitect'sorientation and sensitivity towards the traditionalarchitectural elements. These elements were the indispensable part of the traditional architecture and can be seen in Badshahi Mosque (which means Kings Mosque) and Wazir Khan's mosque in Lahore. Theproposed location of the tomb of Muhammad Ali Jinnah founder of Pakistanon the central axis (Fig. 1B), instead of any public building was in contrast with the modern urban planning, where the capitol complex or other public

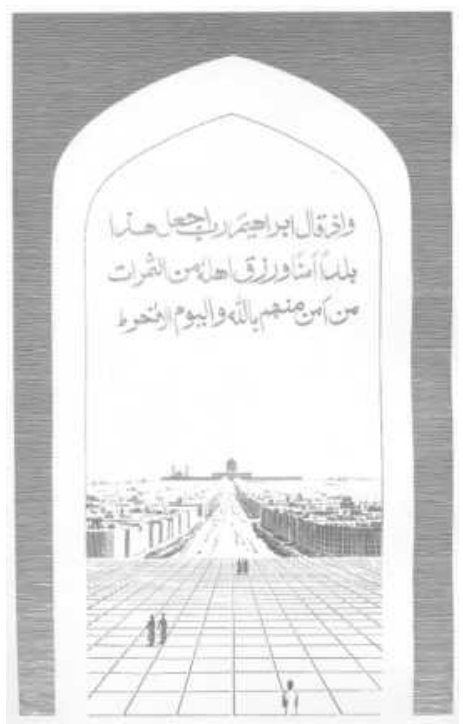

Figure 1b. Proposed Sketch of the Central Axis leading to Jinnah Tomb in Karachi - The irst Federal Capital of Pakistan.

Image Source: Government of Pakistan, Report on Greater Karachi Plan, 1952 . Karachi Development Authority 


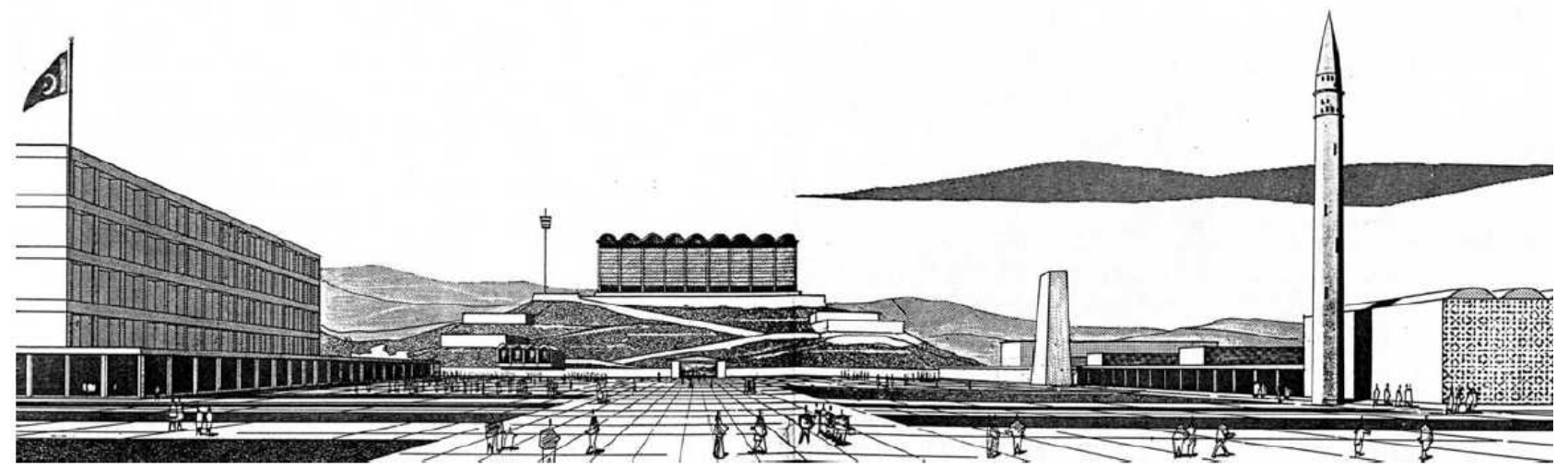

Figure 2. Proposed Sketch for the President House and allied facilities in Islamabad Source: Doxiadis Archives, Athens (Greece ) , DOX-PA 89 , pp 125,1960

buildings hold a dominating position. In a detailed analysis of MRV' splan, Ahmed Zaib Khan Mahsud designated this shift in the plan as symbolically important and narrates that it depicts the state's vision. He states that "The e is no Presidential Palace, rather the symbolic, as well as the real focus of the capitol complex, is Jinnah's Mausoleum".[10]

In 1960, the military ruler, President Ayub Khan announced the development of a new capital in Islamabad, the word which means the "city of Islam". Overwhelmed with the idea of bringing Pakistan into the league of progressive nations, Ayub's regime agenda was to develop a new city which can be comparable to the world capitals, especially with Chandigarh: The brainchild of Le-Corbusier, which was situated in the state of Punjab in neighboring India. Ayub's vision was shaped-upby the idea of using "modernity for representation" [17], an approach which was adopted by most of the new nation states formed after 1900 . Most important of them was Turkey [2], a country which Muslims of India idealized for a long time as a beholder of Islamic Caliphate. Other such examples include but not limited to Indonesia [13], Brazil [7] and India [23]. Constantinos Apostolou Doxiadis was selected to design the city. He designed the city following his theory of Ekistics and selected the gridiron to provide a framework for the development of the city of future [5]. The selection of gridiron served dually,on the one hand it was an appropriate element for creating a functional plan and accommodating the future growth, and on the other, as described by famous Pakistan theoretician KKM, it was "regarded as Islamic because of its geometric design" [18].

In the sketch prepared by the Doxiadis for the Capitol Complex in Islamabad (Fig.2) the Presidential Palace building rose like a pyramid between a number of other buildings, the prominent among them is the grand national mosque (on the extreme right) and secretariat office (on extreme left). Th oughout history, we can find a number of prominent buildings being placed in the highest places to reflect the power and leave a strong impression on people. A comparison between MRV plan designed in 1952 for the Pakistan's first capital in Karachi and plan of Islamabad reveals that Doxiadis had allocated the Presidential Palace a more symbolic position by placing it at the end of the major axis, later know as Jinnah Avenue. This road was also used to stage the military power on Pakistan's resolution day, which is, March 23. The military show off is an attribute which this road shares with "Tiananmen Square", Beijing, China and "Red square" Kremlin, Russia.

Doxiadis was well aware of the urban planning and architectural elements used in "Indus valley civilization" and being a Greek Architect was well informed about the symbolic role of placing the politically important building on the highest plateau. Dr. Mahsud interprets that the configuration of "Presidential Complex" in Islamabad proposed by Doxiadis was inspired by a Greek acropolis (Fig.4) [10], however, a parallel can also be drawn between the citadel, in Mohenjo-Daro (Fig. 3) a city of Indus valley civilization, and the presidential complex [20]. This idea is aligned with the studies of Daeschel which he conducted with reference to the city of Islamabad. Daeshcel claims that Doxiadis took a lot of references from the Indus valley civilization while designing the city of Islamabad. Indeed, he narrates that "when it came to designing a logo for the project .... Doxiadis proposed a motif from the Indus Valley civilization that had existed in the area of West Pakistan between 3000 and $2000 \mathrm{BC}$ " [9].

Designation of a politically prominent location to the Presidential Palace was in contradiction with the philosophy of the country, that was supposed to reinforce the democratic 


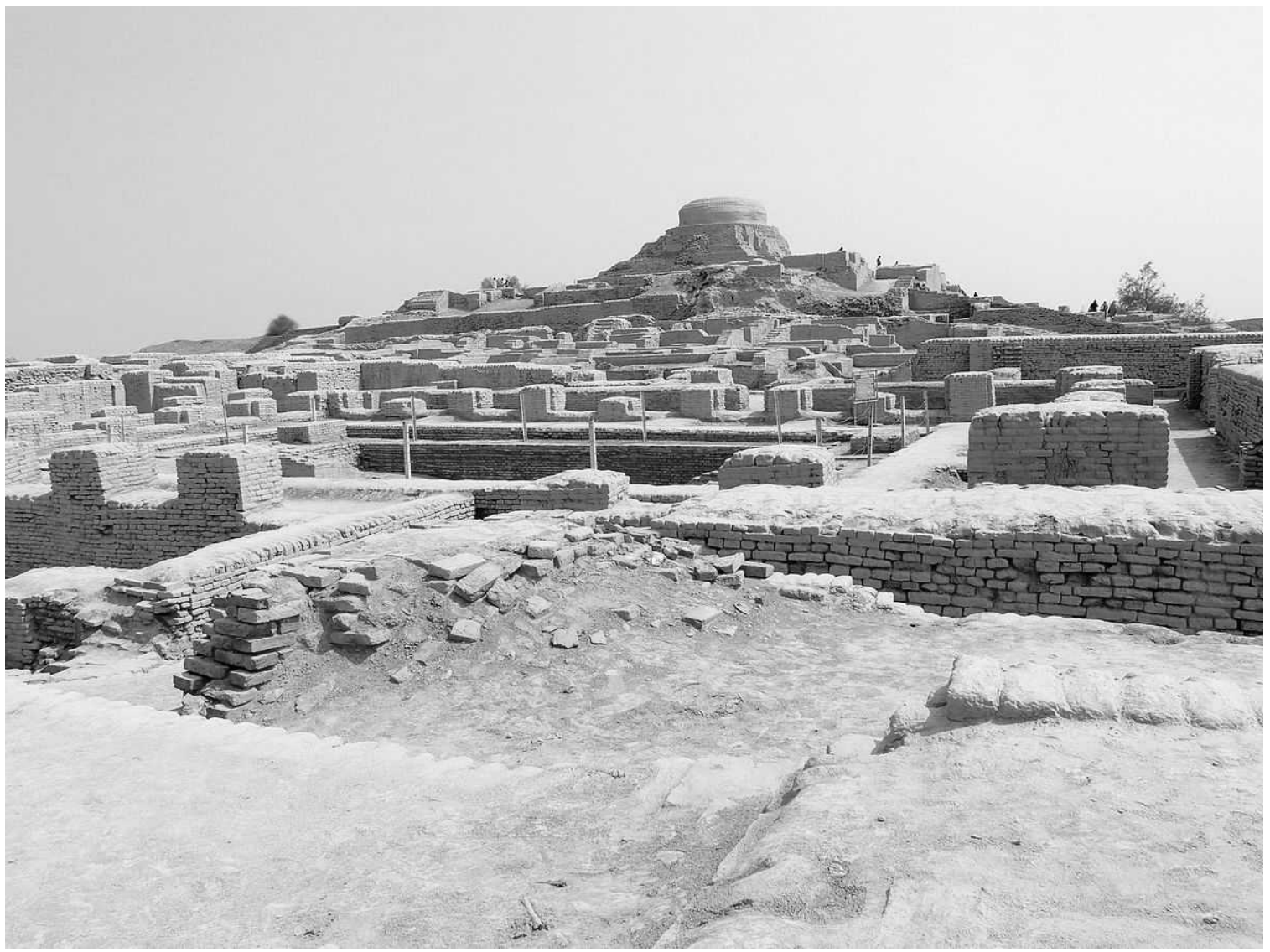

Figure 3. The ound, Moenjo Darro.

Source: https://commons.wikimedia.org/wiki/File:Mohenjodaro_-_view_of_the_stupa_mound.JPG.

values. It is important to note that a similar building, that was, Governor's Palace was eliminated from the plan of Chandigarh because it might steer the nostalgia of Imperialism. Although it goes in line with the agendas of a military dictator, who was the biggest proponent of the Presidential system in the country. An aesthetic criticism on the schematic scheme developed for the Presidential Estate by Doxiadis would be difficult However, the straight lines and brutalist facade give us conclusive direction where the ruling regime and architect might want to negotiate. The placement of a grand mosque in the forefront with the Presidential Palace at the background on a mound also highlights the systematic importance of these monuments. In a similar Fashion Naveed, explains that the public buildings in the "Moen jo Darro" (Fig. 3) were placed onto mounds [19]. The reasons for this placement would be more of a symbolic nature than practical one. (It is also remarkable to note that most of the of the cities of ancient Indus valley were designed following a grid iron plan clearly segregating the public building from private). Though not directly addressing the Presidential Complex, KKMquotes text fromNilsson Sten that provides us with a general ideology of state behind the development of State Apparatuses. Sten states: "If the parliament house is then to be built ... the building will be of a substantial size in order to be architecturally impressive, it will have to be carefully designed to reflect our past culture at the same time utilizing modern methods of construction" [21].

Effo ts to seek the detail design of the presidential complex had started in 1962. The term PresidentialComplex generally refers to a group of buildings including the Parliament building. For this purpose, modernist Arne Jacobsen's was hired to design the building. However his design was rejected due to lack of Islamic features and not representing the national sentiments. After Jacobson, Prof. Louis Khan was also rejected owing to the regime's intention of incorporating the Islamic elements ${ }^{2}$.It is important to note that Prof. Khan was later selected to design the Parliament building in East Pakistan (presently Bangladesh) which is one of the most celebrated building in South-Asia, constructed after independence. Th search for an architect whose architecture is in line with the current trends of architecture yet he is sensitive about the regime's intention of producing culturally and religiously sensitive design lead to the appointment of EDS[24].

${ }^{2}$ Kamil Khan Mumtaz, Architecture in Pakistan (Singapore: ButterworthHeinemann, Asia, 1989). 


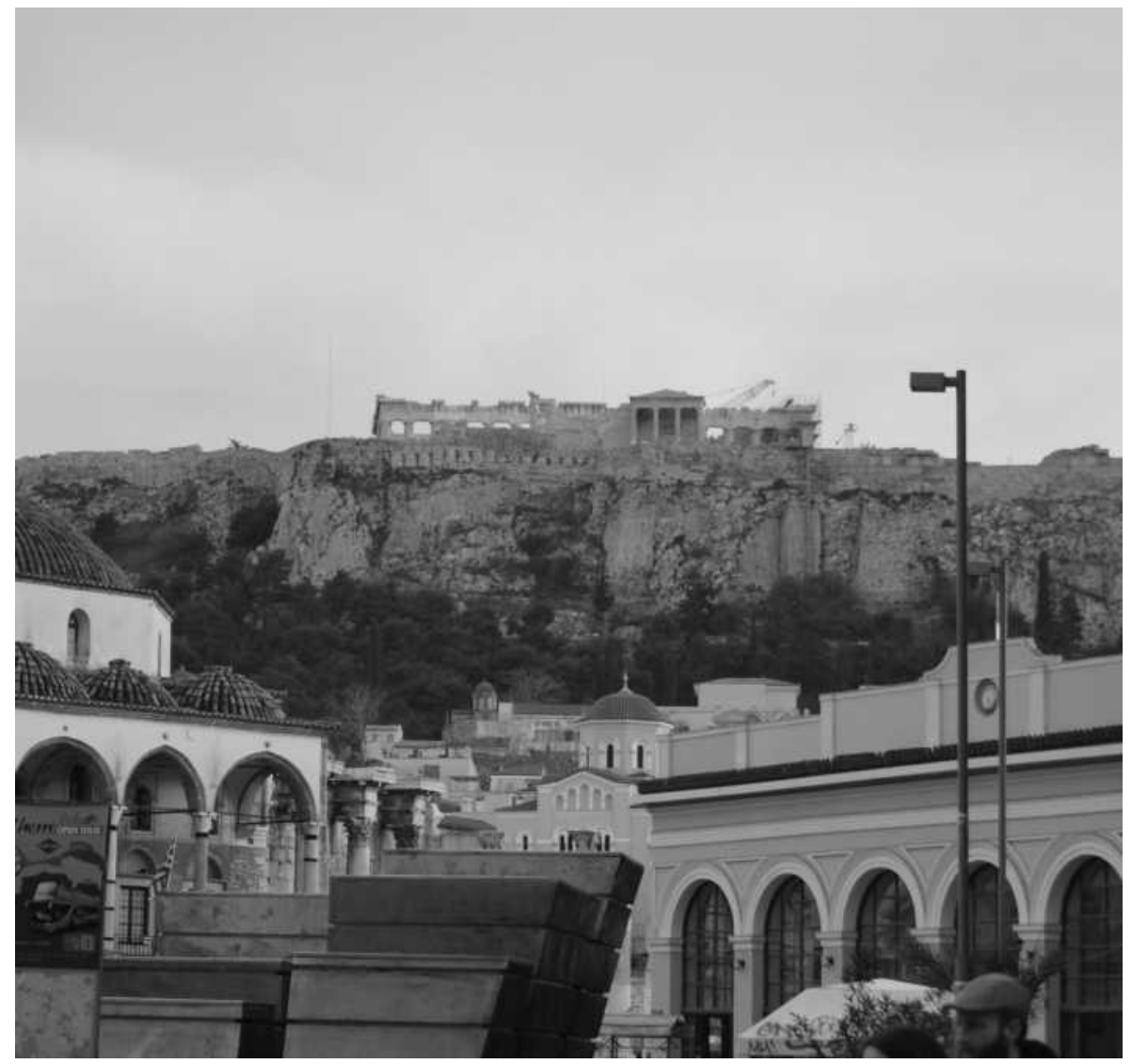

Figure 4. Acropolis View From Monastiraki Square, Athens, Greece Source: Author

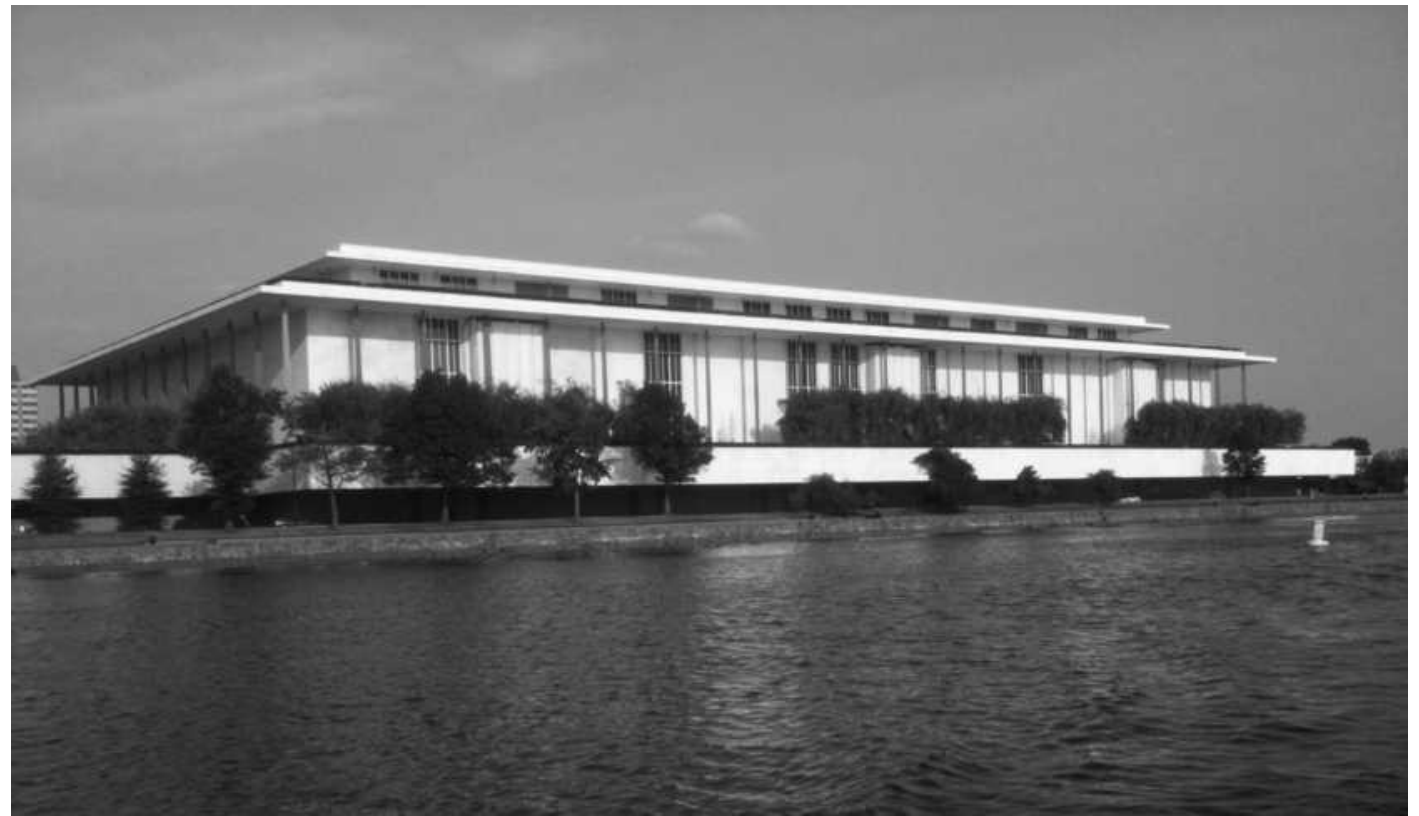

Figure 5: John F. Kennedy Center for the Performing Arts

Image Source: http://www.wikiwand.com/en/John_F__Kennedy_Center_for_the_Performing_Arts 


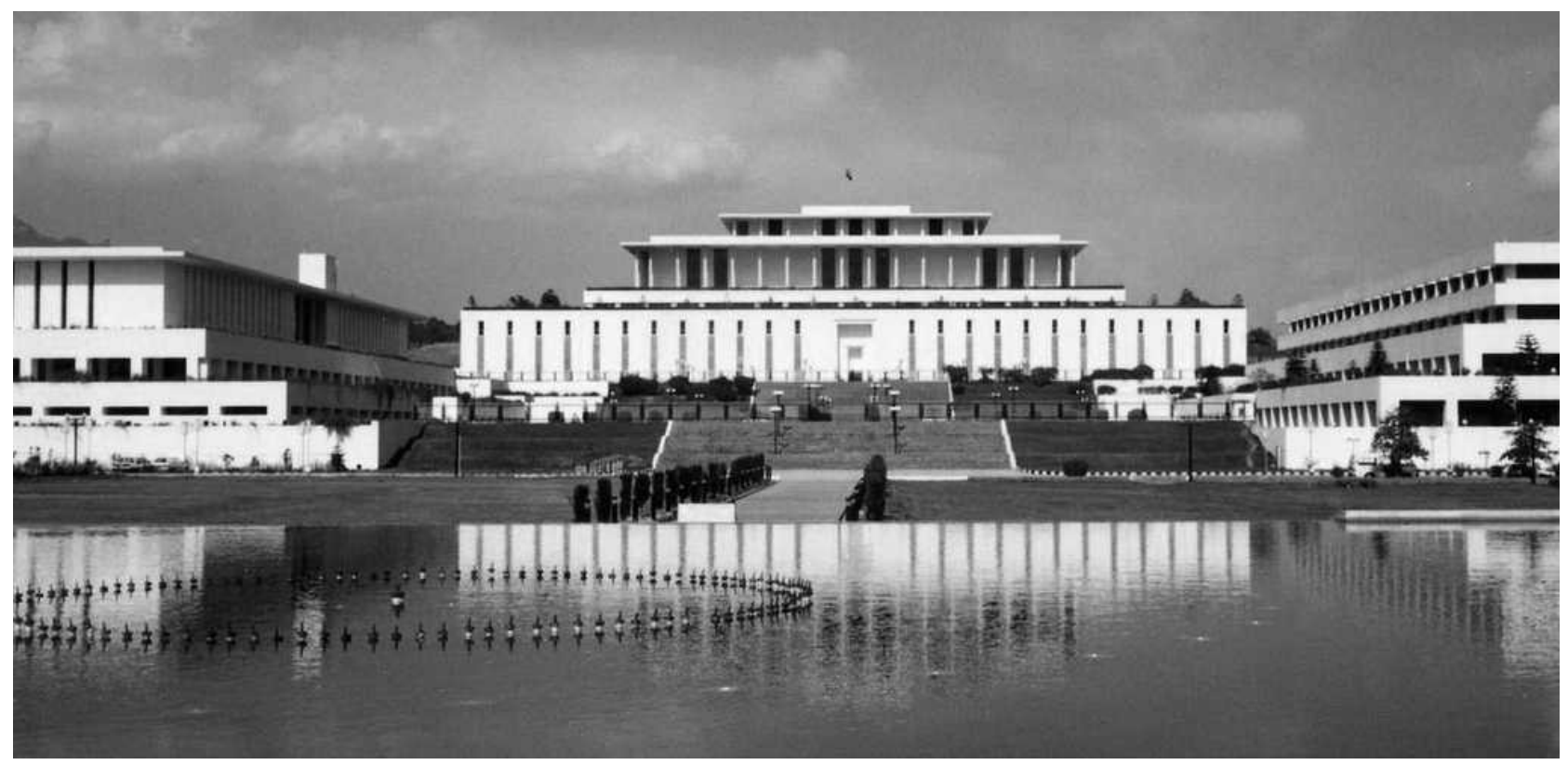

Figure 6. President House in Islamabad

Image Source: https://www.pinterest.com/pin/302093087475095357/?autologin=true

The design of the EDS for the presidential complex was highly appreciated by regime and critics [18]. Though from the first appearance, it seems like a mere replication of the international style and EDS prior work in the United States. The brutalist rendering and straight line on facade of the presidential complex bring it in comparison with the John F. Kennedy center in United States (Fig. 5) designed by EDS.

\section{Pakistan Institute of Nuclear Science and Technology (PINSTECH)}

Titled as 'designed like a mosque' by NewsweekPakistan [14] and 'Nuclear Taj Mahal' by Physics Today [16], the firs master plan for PINSTECH was made by US company AMF Atomics, whose main responsibility was to design the atomic reactor. The Head of PINSTEC, Mr. Usmani together with the renowned scientist Mr. Salaam, who were well aware of the symbolic importance of the building, had rejected the plan, which in Leslie'swords states "lacks the imagination".Later on Edward Durrel Stone was appointed as the designer of the buildings, who is well known for "blending eastern elegance with western functionality" [25] and who's recently completed US Embassy building in India was a superb blend of this statement. [16] The institute was constructed in two stages. Firstly "reactor building and ancillary facilities were completed. The second stage, yielded in the construction of various laboratories, workshop, library and auditorium in 1974" [25].
Prof. Leslie provides a brief detail about the construction and finishing of PINSTECH building and emphasis that not only the interest of Salam and Usmani, two pivotal decision makers at PINSTECH, but also EDS's sensitivity towards regional architecture that resulted in the hybrid styled building. He states that although functionally bound to adhere with the international standard like AEC, "Stone still found plenty of room for architectural improvisation". Its dome, minaret, arches, veranda, water bodies and its orientation toward Holy Kaaba gives it more mosque like a feeling then an atomic reactor. "Instead of exposed concrete,Stone finished the thin-shell dome with waterproof stucco in an ornamental arrangementof slender rounded arches capped by concentric rings of circles. He then outlined the archesand circles with embedded gold mosaic tiles. In the moat around the base of the reactordome, he arranged fountains and spotlights, to eye-catching effect [15]. The design for the PINSTECH by EDS was not only the reincarnation of physical elements but also beholds the metamorphic and symbolic meanings. Just like the Presidential Complex EDS placed the whole building on a raised platform which enhancesits impression on the user [14]. Following the functional need of the reactor, which was designed as a minaret,EDS placed it in geometrically designed water bodies with fountains, a common feature that forms an integral feature in the buildings constructed by the great Mughal (Fig. 9). In addition, the reactor top was covered with a large dome and placed it along thecentral axis, adding a symbolic importance to the mass of building (Fig. 10). 


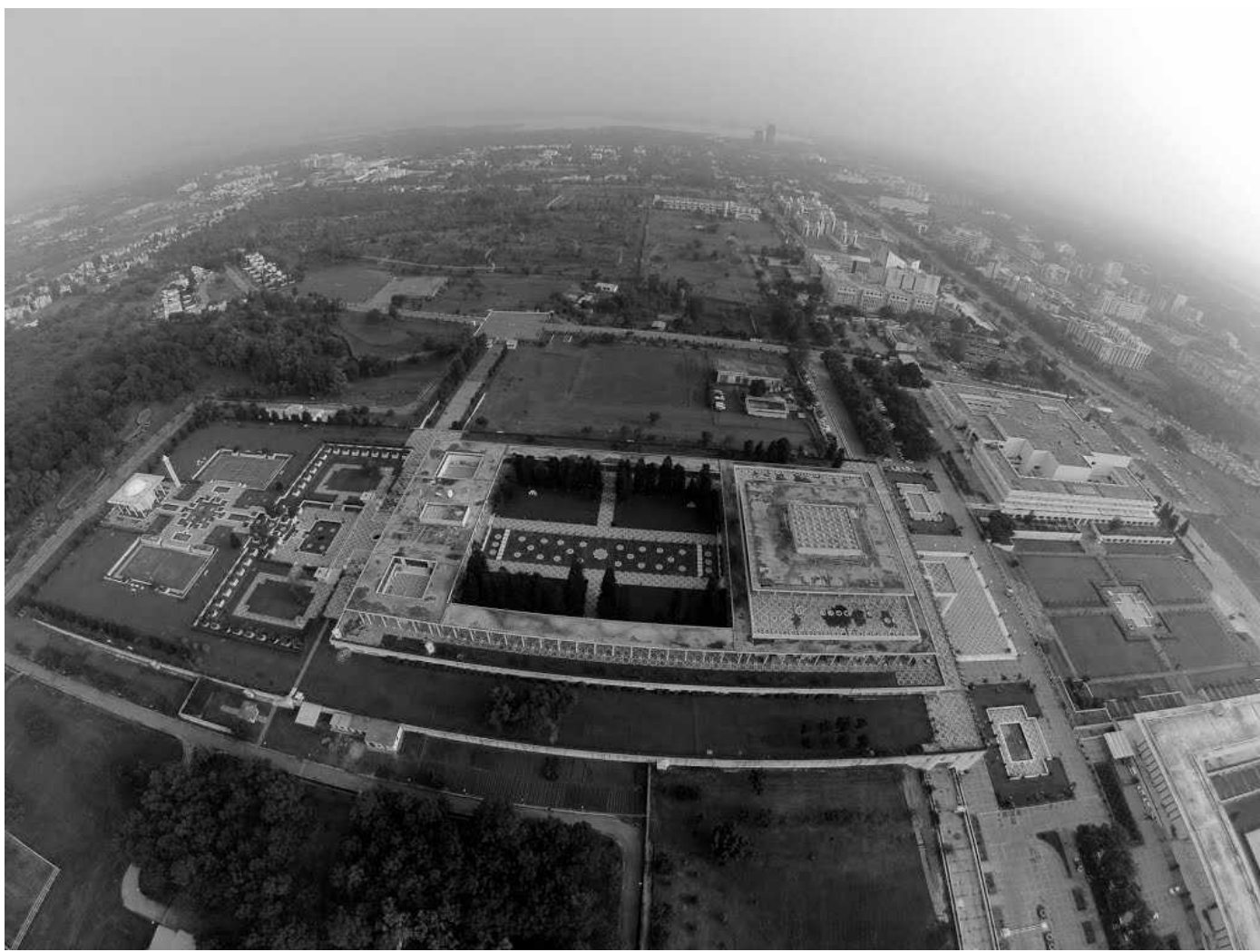

Figure 7. Drone Camera View Of The resident House, Islamabad. Source: Mr. Yameen Mustafavi, Tehreek -e - Minhaj Ul Quran Media Wing

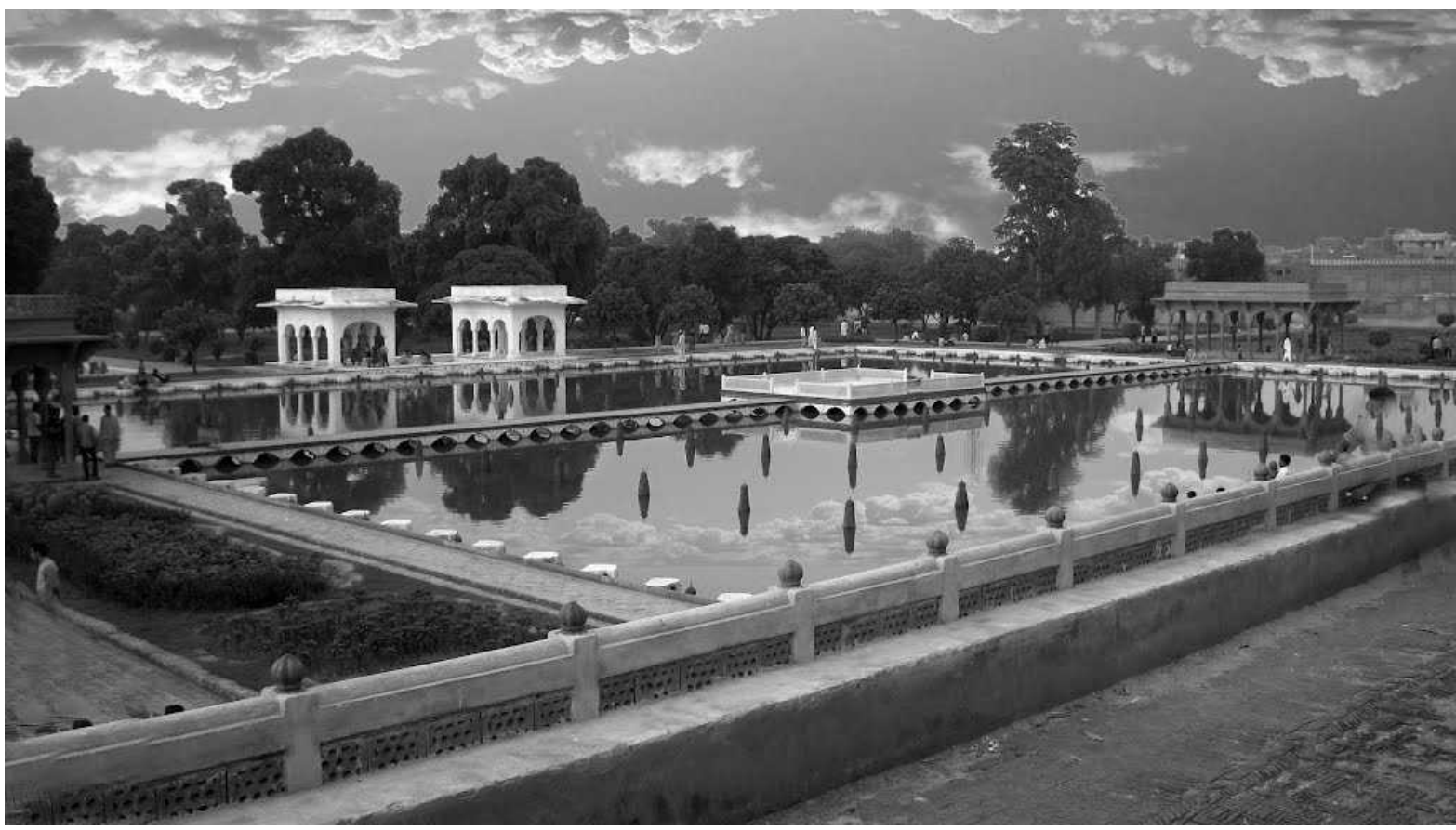

Figure 8. Shalimar Garden, Lahore

Source : http://mapio.net/pic/p-79348358/ 


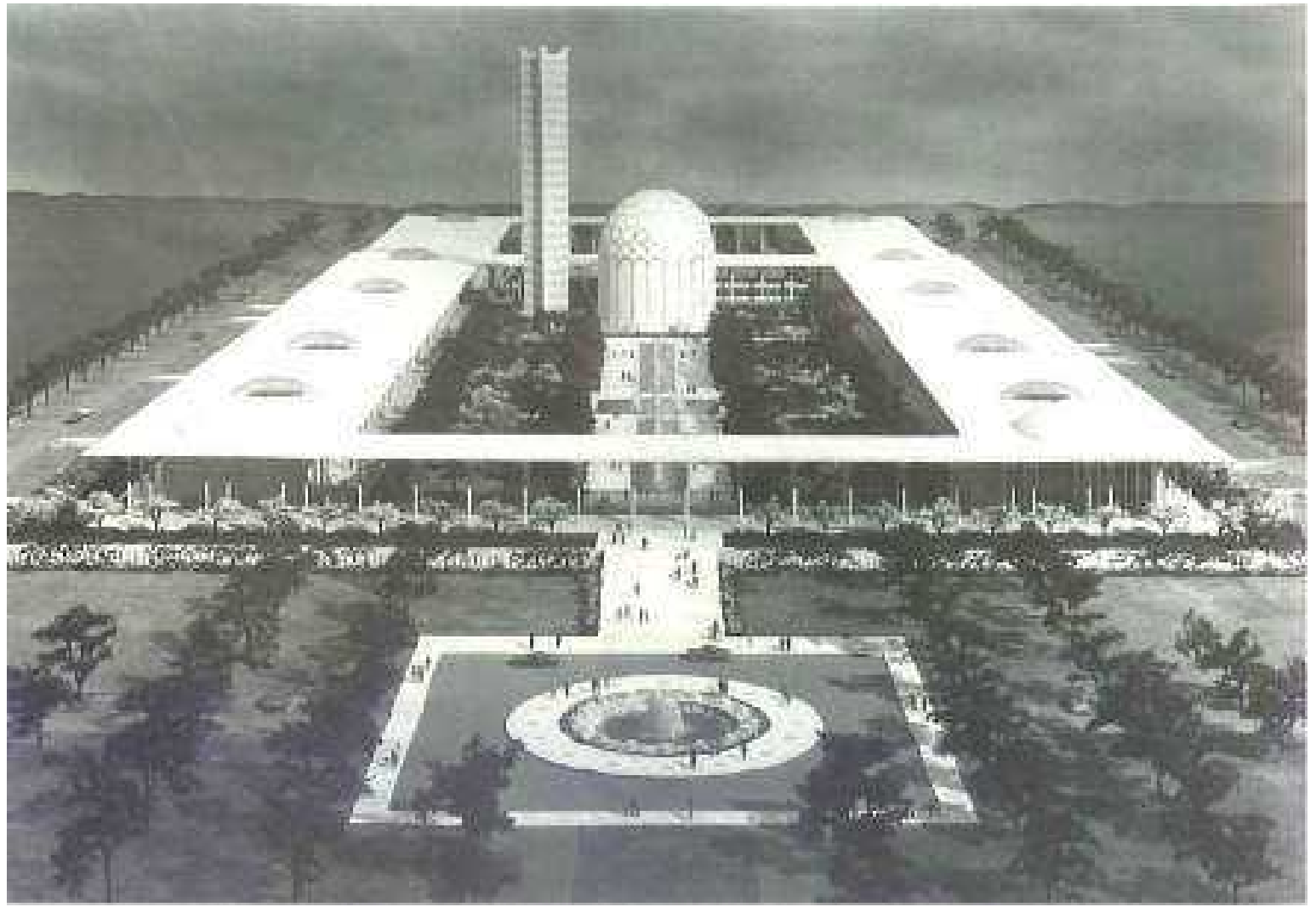

Figure 9. Pakistan Institute of Nuclear Science and Technology

Image Source: Edward Durell Stone Papers, Special Collections, University of Arkansas Libraries.

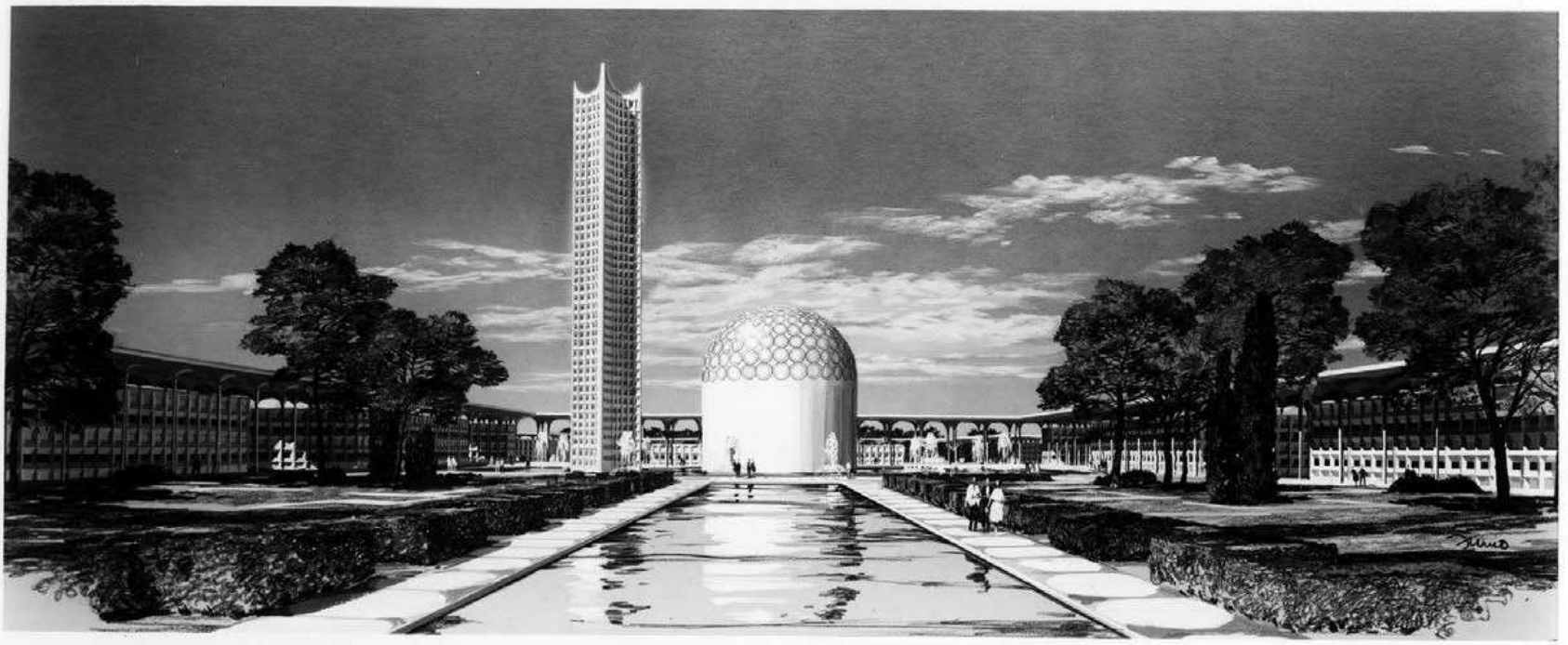

Figure 10. Artist Rendering of Pakistan Institute Of Nuclear Science And Technology Image Source: Edward Durell Stone Papers, Special Collections, University of Arkansas Libraries. 


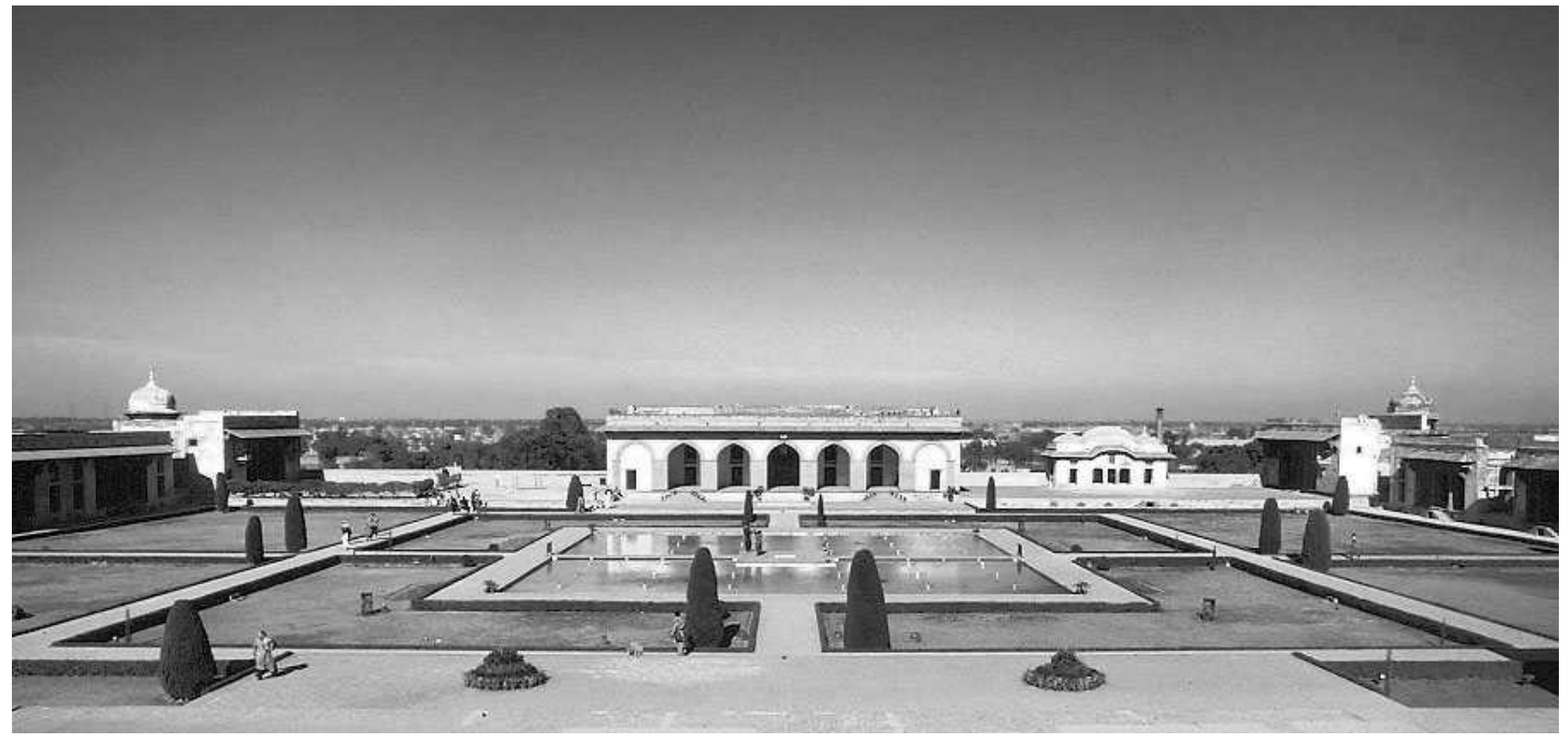

Figure 11. Jahangir's Quadrangle, Lahore Fort

Image Source : http://www.kamit.jp/24_pakistan/xlah_1eng.htm

Though, in contrast to its main function EDS treated the landscaping of this building just like Gardens of the great Mughals [26]. Prof. Leslie states while explaining the landscape that:

"Just beyond the entrance, a long, narrow water channel with a central row of fountains $\mathrm{fl}$ wed towards the reactor, with paved pathways, gardens and benches on either side. The fountains doubled as cooling jets for the air conditioning system" [15].

\section{Conclusion}

The modernist architecture in the newly formed capital of Pakistan, was appropriated by grounding in the tradition, mainly in the building built or utilized by Muslim ruler of India, as desired by the ruling regime. The states agenda was translated into architecture bya number of architects. Edward Durrell Stone, an American architect, was among the prominent architects who undertook this task. His ability to provide a hybrid solution was the key to his appointment as one of the favorite architects of the ruling regimes. Daeschel narrated EDS contextual acclamationas "Stone quickly learned to make copious, if often merely rhetorical, a reference to Islamic building norms in his sales pitch". Daeschel also criticized his approach as "showing little sensitivity to such matters in actual architectural space" [9].The latter part might be correct for some of the stone works in Pakistan like Wapda House, Lahore. For quite a longthe facade ofthe presidential complex was also read in contrast to his study of Islamic architecture, the paper however has shed light on the fact that the present façade was "normalized' after the removal of certain element proposed by EDS. Various studies of the plan and the pictures taken from drone cameras also reveal that the constructed space exhibits a strong influence of the Mughal geometric space as evident in the Jahangir's Tomb, Shalimar Garden and Lahore Fort (Fig. 11).

The skillful mastery of EDS which he utilized while translating the modernist agendas of place making and monumentality in the specific geographical location is terrific. The two buildings, discussed in this paper, designed by EDS are in line with his study of traditional architecture in Pakistan and exemplify his expertise as a modern master. Also, these building provided a foundation for the development of regionalist discourse on architecture in Pakistan. A detailed analysis of the buildings of EDS reveala conceptual agreement between EDS and Khawajas definition of "Islamic" architecture. Islamic architecture to Khwaja does not only correspond to specific building elements but refers to architecture constructed in the geographical areas inhabited or ruled by Muslims with broader aims covering all the required symbolic and functional aspect [12]. The main attribute of this architecture is more "conceptuallsymbolic in nature rather than material'. However, a further debate is required to locate the diffe ences (if any) between the so-called "Islamic" architecture and other forms of architecture practiced across the world. 


\section{References}

[1] Akcan, E. (2012). Melancholy in Translation. In Architecture in Translation: Germany, Turkey, and the Modern House, Duke University Press.

[2] Bozdogan, S. (2002). Modernism and Nation Building: Turkish Architectural Culture in the Early Republic. New edition, Seattle, Wash. u.a.: University of Washington Press.

[3] Chaudhry, Nazir A. (2002). Harappa: The Cradle of Our Civilization. Lahore: Sang-e-Meel Publications.

[4] Daechsel, M. (2015). "From 'great Plan' to Great Project." In Islamabad and the Politics of International Development in Pakistan, Cambridge University Press.

[5] Doxiadis, Constantinos A. (2016). Ekistics, the Science of Human Settlements Available athttp://www.doxiadis. org/Downloads/ecistics_the_science_of_human_ settlements.pdf(Accessed April 19, 2016).

[6] Hasan, A.(2016). Planningand Its Assumption. Available at http://arifhasan.org/wp-content/uploads/2012/08/ P13_Planning-and-its-Assumptions.pdf (Accessed April 19, 2016).

[7] Holston, J. (1989) The Modernist City: An Anthropological Critique of Brasilia. Chicago: University of Chicago Press.

[8] Hunting, Mary A. (2012). Edward Durell Stone: Modernism's Populist Architect. First Edition: W. W. Norton \& Company.

[9] Islamabad and the Politics of International Development in Pakistan. (2015). Islamabad and the Politics of International Development in Pakistan. Cambridge University Press

[10] Khan, A. Z. (2013). On Design and Politics of Co-producing Public Space: The Long Marches and the Reincarnation of the 'Forecourt' of the Pakistani Nation', International Journal of Islamic Architecture 2: 1, pp. 125-156, doi: 10.1386/ ijia.2.1.125_1

[11] Khosla, R. (1992). A Period of Renaissance. Review of TheArchitecture of Mughal India. Social Scientist 20 (11), 58-61. doi:10.2307/3517780.

[12] Khwaja, Zaheerud D. (2016). The Spirit of Islamic Architecture. Avaialbale at http://archnet.org/system/ publications/contents/3536/original/DPC0055. pdf?1384775526. (Accessed April 20, 2016).

[13] Kusno, A. (2000). Behind the Postcolonial: Architecture, Urban Space and Political Cultures in Indonesia. First edition. London ; New York: Routledge.
[14] Leslie, Stuart W. (2016). Atomic Isolation. In Newsweek Pakistan. Available at http://newsweekpakistan.com/ atomic-isolation.

[15] Leslie, Stuart W. (2015). Atomic Structures: Th Architecture of Nuclear Nationalism in India and Pakistan. History and Technology 31(30), July, 2015). doi:10.1080/07341512.2015.1124635.

[16] Leslie, Stuart W. (2015). Pakistan's Nuclear Taj Mahal. Physics Today 68(2), pp. 40-46. doi:10.1063/ PT.3.2688.

[17] McGarr, Paul M. (2013). The Cold War in South Asia: Britain, the United States and the Indian Subcontinent 1945- 1965. Cambridge University Press

[18] Mumtaz, Kamil K. (1990). Architecture in Pakistan. London: Architectural Press.

[19] Naveed, Muhammad B. (2016). Harappa: An Overview of Harappan Architecture and Town Planning. Retrieved from http://www.ancient.eu/article/695

[20] Nazir Ahmad C. (2002). Harappa: The Cradle of Our Civilization. Lahore: Sang-e-Meel Publications.

[21] Nilsson, Sten A.(1973). The New Capitals of India, Pakistan and Bangladesh. Scandinavian Institute of Asian Studies Monograph Series No. 12. pp. 230. Lund, Studentlitteratur, 1973. Journal of the Royal Asiatic Society of Great Britain \& Ireland, 108(2), 175-175. doi:10.1017/S0035869X0013360X

[22] Pakistan Dawn (2014). Pakistan Wants to Build More N-Power Plants, IAEA Told. Retrieved from http:// www.dawn.com/ news/1134378

[23] Prakash, V. (2002). Chandigarh's Le Corbusier: The Struggle for Modernity in Postcolonial India. First Edition. Seattle. University of Washington Press.

[24] Timothy R. and Mohammad G. (2013). Edward Durrel Stone: Architectural Works in Asia and North Africa. Paper presented at 2nd international conference on Sustainable Cities, Urban Sustainability And Transportation. Baltimore. pp. 232-238. WSEAS Press

[25] USA, IBP. (2012). Pakistan Nuclear Programs and Projects Handbook - Strategic Information and Regulations. IBP USA

[26] Wescoat, James L. and Joachim Wolschke, B. (1996). Mughal Gardens: Sources, Places, Representations, and Prospects. Dumbarton Oaks. 